\title{
PENINGKATAN KEMAMPUAN MENULIS ESAI BAGI SISWA SMA N 2 TUALANG, KECAMATAN TUALANG
}

\author{
Evizariza $^{1}$, Alvi Puspita ${ }^{2}$, TM Sum ${ }^{3}$ \\ ${ }^{1}$ FIB Universitas Lancang Kuning Pekanbaru \\ ${ }^{2}$ FIB Universitas Lancang Kuning Pekanbaru \\ ${ }^{3}$ FIB Universitas Lancang Kuning Pekanbaru
}

evizariza@unilak.ac.id, alvipuspita1003@gmail.com, tm_sum@yahoo.com

\begin{abstract}
Abstrak
Program Iptek bagi Masyarakat (IbM) yang tim lakukan adalah Peningkatan Kemampuan Menulis Esai Bagi Siswa SMA N 2 Tualang, Kecamatan Tualang. tingkat kegiatan literasi di SMA 2 Tualang masih rendah padahal di sekolah tersebut guru Bahasa Indonesia berjumlah lima orang. Namun walau demikian tingkat keaktifan siswa dalam bidang tulis-menulis bisa dikatakan kurang. Dulu pernah ada buletin sekolah tapi sudah lama vakum karena guru penggeraknya sudah pindah. Hal ini mengindikasikan bahwa persoalan penulisan kreatif atau pun juga hal lain yang berkenaan dengan sastra semisal pembacaan puisi, belumlah memperoleh perhatian dan mendapat porsi bimbingan yang semestinya. Target yang ingin dicapai yakni meningkatnya minat dan kemampuan siswa dalam menulis esai. Sebagai nilai tambahan yang ingin diperoleh yaitu tergalinya lokalitas daerah tempat pelatihan ini diadakan melalui tulisan yang nanti akan dihasilkan oleh para siswa. Metode yang tim lakukan untuk mencapai target tersebut adalah metode ceramah, tanya jawab dan praktik. Hasil akhir dari kegiatan Pelatihan Menulis Esai yang diperuntukkan bagi siswa-siswi SMA N 2 Tualang ini adalah munculnya minat siswa menulis esai. Esai-esai tersebut ditulis oleh siswa-siswi pada sesi kedua kegiatan setelah dibekali dengan materi seputar apa itu esai, jenis dan fungsi beserta contoh-contoh esai. Esai-esai karya para peserta tersebut dikumpulkan pada akhir kegiatan pelatihan.
\end{abstract}

Kata Kunci: esai, menulis, siswa, lokalitas

\begin{abstract}
The Science and Technology Program for the Community (IbM) which the team carried out was the Improvement of Essay Writing Ability for Students of SMA N 2 Tualang, Tualang District. The level of literacy activities at SMA 2 Tualang is still low, even though the Indonesian language teacher means five people. However, the level of student activeness in writing can be said to be lacking. In the past, there was a school bulletin but it has been on hiatus for a long time because the teacher who moved it. This indicates that problems related to creative or other matters relating to literature, such as reading poetry, have not received attention and have received the proper portion of guidance. Targets to be achieved in seeking students' interests and abilities in essay writing. As an additional value to be obtained, namely the exploration of the locality of the area where the training was held through writing which would later be produced by students. Methods that work to achieve these targets are lectures, questions and answers and practice. The final result of the Essay Writing Training for SMA N 2 Tualang students is a test of the students' interest in writing essays. The students wrote the essays in the second session after being provided with material about what essays are, types and functions along with essay examples. The participants' essays were collected at the end of the training activity.
\end{abstract}

Keywords: essays, writing, students, locality 


\section{PENDAHULUAN}

Sebagaimana keterampilan berbahasa lainnya (menyimak, membaca dan berbicara), keterampilan menulis yang dalam hal ini menulis esai adalah sesuatu yang penting. Banyak manfaat dari menulis. Beberapa diantara manfaat tersebut menurut Akhadiah dkk (1998: 1-2) adalah membantu kita mengenal kemampuan dan potensi diri, mengembangkan berbagai gagasan, belajar mengorganisasikan gagasan secara sistematik dan dapat mengungkapkannya secara tersurat, membuat kita dapat meninjau serta menilai gagasan kita sendiri secara objektif, mendorong kita belajar secara aktif, belajar menganalisis serta membiasakan kita berpikir dan berbahasa secara tertib.

Dari banyak manfaat tersebut salah satu poin utamanya adalah bahwa menulis erat kaitannya dengan pengembangan pikiran dan penyampaian gagasan. Pelajar sebagai agen of change dan calon cendekia muda semestinya memang harus aktif dalam menulis. Lewat tulisan, pelajar dapat menyampaikan gagasan-gagasan, pikiran serta pengetahuannya sehingga bisa dibaca oleh khalayak ramai. Selain itu, menulis juga membuat seseorang bisa lebih peka terhadap sekelilingnya. Karena selain soal teknik, intuisi dan kepekaan juga merupakan modal utama dalam menulis. Menulis mengasah pikiran sekaligus pula mengasah rasa. Namun, persoalannya banyak pelajar yang kurang mampu menulis dengan baik. Indikasi ini bisa ditemukan dari kurangnya penulis muda Riau yang muncul diberbagai media masa, baik cetak maupun online. Padahal dengan menulis terbuka lowongan pekerjaan yang mampu meningkatkan taraf ekonomi.

Salah satu penyebab dari persoalan ini adalah kurangpahamnya pelajar tentang arti penting menulis. Menulis telah menjadi sebuah mitos yang menakutkan. Perpustakaan sebagai salah satu ujung tombak gerakan literasi pun masih belum pula diberdayakan maksimal. Guru yang tinggal di desa, butuh waktu lebih lama dan energi lebih besar untuk bisa intens pada hal-hal yang berkenaan dengan literasi. Bahwa kunci paling dasar adalah kesadaran. Dari kesadaran akan muncul minat dan kecintaan. Cinta membaca pada mulanya. Setelahnya adalah cinta menulis. Oleh karena itu, tim memandang penting kegiatan pelatihan yang akan dilakukan ini.
Berdasarkan kondisi tersebut maka kami merasa perlu untuk mengadakan pelatihan menulis esai. Mengapa esai? Mengapa tidak genre lain? Alasannya karena bentuk esai adalah bentuk tulisan yang lebih sederhana dibandingkan bentuk-bentuk lain semisal puisi, cerpen atau pun artikel. Sementara, melihat bagaimana kondisi mitra, yang boleh dikatakan berada pada level paling bawah (level membangun kesadaran dan kecintaan akan membaca dan menulis), maka bentuk esailah yang menurut tim paling cocok dan tepat.

SMA N 2 Tualang merupakan salah satu sekolah yang berada di Kecamatan Tualang, KabupatenSiak. Letak sekolah ini di Jl.Wijawangsa, Kampung Tualang, Kec. Tualang, Kab.Siak, Prov. Riau.

Berdasarkan bincang-bincang dengan salah satu guru yang mengajar di sana (Tarmizi, S.Pd), diperoleh informasi bahwa tingkat kegiatan literasi di SMA 2 Tualang masih rendah padahal di sekolah tersebut guru Bahasa Indonesia berjumlah lima orang. Namun walau demikian tingkat keaktifan mahasiswa dalam bidang tulis-menulis bisa dikatakan kurang. Dulu pernah ada buletin sekolah tapi sudah lama vakum karena guru penggeraknya sudah pindah. Hal ini mengindikasikan bahwa persoalan penulisan kreatif atau pun juga hal lain yang berkenaan dengan sastra semisal pembacaan puisi, belumlah memperoleh perhatian dan mendapat porsi bimbingan yang semestinya. Padahal, sebagaimana yang telah dipaparkan pada bagian Analisis Situasi di atas telah dikemukakan tentang pentingnya menulis, yang salah satunya termasuk menulis esai. Di tambah lagi jika kita merunut pada teori kecerdasan yang dipaparkan oleh Prof. Howard Gardener ( seorang ahli riset dari Amerika), bahwa jenis kecerdasan anak bisa digolongkan menjadi delapan. Salah satu kecerdasan tersebut adalah kecerdasan linguistik. Jika kecerdasan ini diasah dengan baik maka anak berpotensi menjadi individu yang sukses dalam bidang yang berhubungan dengan bahasa (komunikasi baik lisan maupun tulisan). 


\section{METODE}

Kegiatan $\mathrm{I}_{\mathrm{b}} \mathrm{m}$ dilakukan kepada siswa SMA 2 Tualang, Kecamatan Tualang. Jumlah siswa yang mengikuti pelatihan ini 18 orang. Peserta pelatihan berdasarkan rekomendasi guru.

Pada kegiatan Pengabdian kali ini, tim memilih lokasi luar ruang. Hal ini berdasarkan hasil dialog dengan salah seorang guru SMA N 2 Tualang, Tarmizi S,Pd. Kegiatan yang dilakukan adalah pelatihan kepenulisan. Jadi jika dilakukan di luar ruang harapannya kreatifitas anak bisa lebih tergali. Tempat yang dipilih sebagai lokasi kegiatan adalah objek wisata Teluk Jongkang, sebuah objek wisata alam yang terletak di tepian Sungai Siak. Harapannya, para peserta nantinya bisa menulis esai deskriptif tentang objek wisata ini dan bisa digunakan sebagai bahan promosi Teluk Jongkang tersebut.

Kegiatan ini dimulai dengan bincangbincang dengan para peserta. Tim bertanya apakah mereka suka menulis atau tidak. Rata-rata peserta menjawab tidak suka menulis dengan alasan tulisan mereka jelek. Ada juga yang menjawab kalau ia tidak menulis tapi mengetik. Hanya ada satu orang peserta yang sudah terbiasa menulis dan mengelola sebuah blog.

Kemudian, sesi perkenalan dilanjutkan dengan penyampaian materi dengan metode ceramah. Materi yang disampaikan yaitu tentang apa itu esai, bagaimana cara menulis esai yang baik, tentang PUEBI, dan yang terakhir tentang proses mengedit tulisan. Setelah itu dibuka sesi tanya jawab. Kemudian terakhir diteruskan dengan sesi praktek.

Menjelaskan langkah-langkah sistematis yang dilakukan dalam kegiatan pengabdian masyarakat.

\section{HASIL DAN PEMBAHASAN}

Hasil akhir dari kegiatan Pelatihan Menulis Esai yang diperuntukkan bagi siswa-siswi SMA N 2 Tualang ini adalah munculnya minat siswa menulis esai. Esai-esai tersebut ditulis oleh siswa-siswi pada sesi kedua kegiatan setelah dibekali dengan materi seputar apa itu esai, jenis dan fungsi beserta contohcontoh esai. Esai-esai karya para peserta tersebut dikumpulkan pada akhir kegiatan pelatihan.

\section{Luaran}

Terdapat hal menarik dari kegiatan pengabdian kali ini. Ketika tim memulai bincangbincang dengan peserta dan menanyakan apakah mereka suka menulis, hampir semua menjawab tidak suka menulis. Alasan mereka karena tulisan mereka jelek. Ada juga yang menjawab kalau ia tidak menulis tapi mengetik. Hal ini menjadi catatan tersendiri bagi tim.

Menulis yang dipahami rata-rata peserta adalah mencatat, menulis dengan tulisan tangan sebagaimana yang dilakukan dalam proses belajar di sekolah. Mereka belumlah memahami menulis sebagai sebuah aktifitas literasi yang merupakan bagian dari empat keterampilan berbahasa.

Dari jawaban para peserta tersebut tim dapat memetakan bahwa tingkat literasi mereka masih sangat rendah. Jangankan menulis dalam artian sebenarnya, menulis dalam artian mencatat materi di kelas pun mereka masih enggan. Padahal menulis erat kaitannya dengan proses berpikir. Proses berpikir tersebut tentu butuh kerja keras dan ketekunan. Bukan merupakan sesuatu yang instan.

Namun, walau demikian tim optimis karena para peserta antusias mengikuti kegiatan. Mereka menyimak dengan serius paparan-paparan materi yang disampaikan oleh tim. Mereka juga kooperatif sangat mereka diminta untuk langsung praktek menulis.

Menimbang level tingkat kesadaran literasi peserta, maka tim melakukan improvisasi. Pada awalnya rencana yang telah disusun, peserta diminta untuk menulis masing-masing dengan bahan tulisan dari cerita lisan atau cerita rakyat dari kampung mereka. Namun, oleh tim kemudian teknisnya diganti. Peserta dibagi menjadi beberapa kelompok. Satu kelompok terdiri dari dua hingga tiga orang. Mereka kemudian dibebaskan memilih apa yang hendak mereka tulis namun tim mengarahkan pada hal yang terdekat dengan mereka yang bisa mereka amati langsung sehingga memudahkan mereka dalam menuangkannya ke dalam bentuk tulisan.

Setelah kelompok dibagi mereka diminta berpencar. Masing-masing kelompok dibebaskan mencari tempat yang mereka sukai juga dibebaskan memilih jenis tulisan yang mereka sukai karena poin inti yang ingin dicapai bagaimana para peserta

$$
\text { Pendidikan }
$$


merasa nyaman dan bagaimana mereka bisa memiliki pengalaman bahwa menulis itu sebenarnya kegiatan yang menyenangkan.

Para peserta diberi batasan waktu untuk menyelesaikan tulisan mereka yaitu lebih kurang dua jam. Pada tahap ini tim berkeliling memantau perkembangan setiap kelompok dan menanyakan apa saja kendala mereka dalam menyelesaikan tulisan.

Setelah batas waktu yang ditentukan habis, masing-masing kelompok mengumpulkan tulisan mereka. Jumlah keseluruhan kelompok adalah sembilan, artinya terkumpul sembilan tulisan. Dua tulisan berbentuk puisi. Dua tulisan berbentuk cerita naratif dan enam tulisan berbentuk esai deskriptif tentang objek wisata Teluk Jongkang.

\section{KESIMPULAN}

Setelah melakukan pelatihan, tim mengambil kesimpulan bahwa minat dan kemampuan menulis pada siswa SMA N 12 Tualang masihlah rendah. Salah satu faktor penyebab menurut tim adalah kurangnya bimbingan dari pihak sekolah karena keterbatasan SDM yang berkompeten di bidang bersangkutan. Hal pertama yang menjadi tantangan adalah menumbuhkan dan meningkatkan kesadaran para siswa juga pihak sekolah dalam bidang literasi. Namun tim optimis karena para peserta antusias. Artinya dengan bimbingan yang serius dan intens para siswa bisa dibentuk agar cinta terhadap kegiatan tulis-menulis (kegiatan literasi).

\section{Saran}

Melihat dan menimbang situasi di lapangan bahwa siswa-siswi khususnya SMA N 2 Tualang sangat miskin keterampilan menulis, maka kami menyarankan agar ke depan perlu dilakukan banyak pelatihan menulis pada siswa-siswi. FIB dengan pihak sekolah terkait barangkali bisa menjalin kerjasama seperti sekolah binaan literasi misalnya. FIB berperan selaku pembina.

\section{UCAPAN TERIMAKASIH}

Penulis mengucapkan terima kasih kepada Rektor Universitas Lancang Kuning yang telah memberikan dukungan melalui LPPM berupa pengawasan terhadap keberlangsungan program ini.
Penulis juga mengucapkan terimakasih kepada pihak Fakultas Ilmu Budaya Universitas Lancang Kuning selaku penyedia dana demi kelancaran program ini. Penulis juga mengucapkan terimakasih kepada semua pihak, yang tidak dapat disebut satupersatu di sini, yang telah membantu dalam pelaksanaan program pengabdian kepada masyarakat ini. Akhirnya semoga hasil pengabdian ini dapat bermanfaat bagi penulis dan dunia akademis khususnya serta masyarakat umumnya.

\section{Foto Kegiatan}

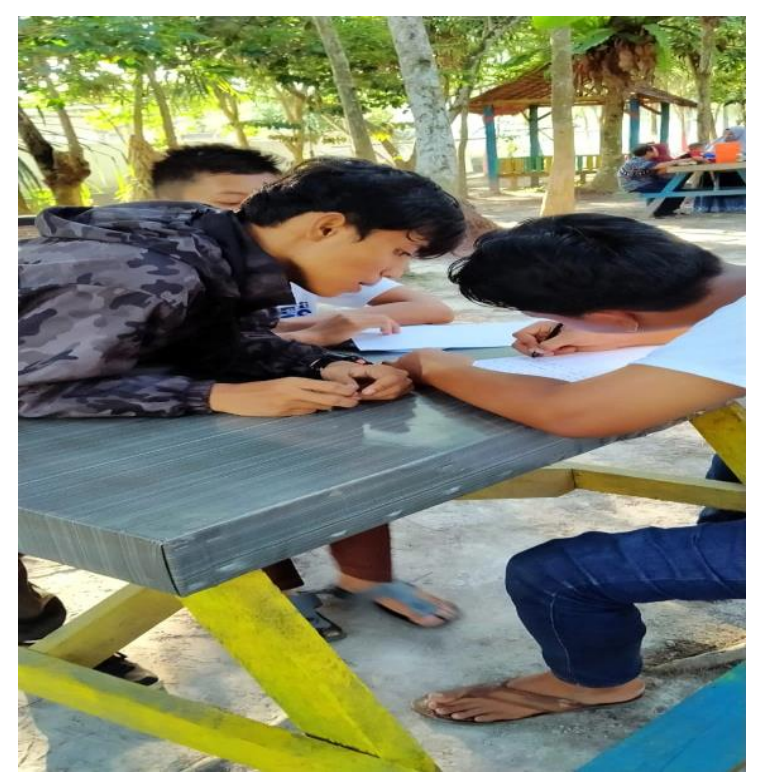




\section{REFERENSI}

Arswendo Atmowiloto. 2004. Mengarang Itu Gampang. Jakarta: Gramedia Pustaka Utama
Keraf, Gorys. 1997. Komposisi Sebuah Pengantar Kemahiran Bahasa. Ende: Penerbit Nusa Indah 